\title{
NEWSPAPERS, FACEBOOK AND TWITTER
}

\section{Intermedial agenda setting in local election campaigns}

\author{
Eli Skogerbø and Arne H. Krumsvik
}

\begin{abstract}
Social media, such as Facebook, Twitter, YouTube and many other services, have established themselves as part of the networked and increasingly hybrid public sphere, extending and transforming it to allow for and facilitate access to all kinds of content and participants. By their sheer ubiquity, these media contribute to changing media ecologies and open new ways and forms of communications between citizens and their representatives. During election campaigns, political parties and their candidates have a number of ways of seeking to mobilise voters by attracting attention to the parties' issues and top candidates. Many of these involve processes of mediatisation, that is, parties and politicians adapt their practices and messages to formats, deadlines and genres that are journalistically attractive. This study seeks to map and understand intermedial agenda setting between social media and traditional news media by analysing data from both local journalism and the social media activity of local politicians during the 2011 Norwegian local election campaigns. Our findings show that local politicians were active on social media as part of their campaigning, yet there was surprisingly little evidence that social media content travelled to local newspapers and contributed to agenda setting, thereby contradicting findings from other settings stating that social media have become established journalistic sources. We suggest that one explanation may lay in the nature of Norwegian politics and culture in which the distance between journalists, citizens and politicians is notably small.
\end{abstract}

KEYWORDS local news; newspapers; Facebook; Twitter; election campaigns

\section{Introduction}

Social media, such as Facebook, Twitter, YouTube and many other services, have established themselves as part of the networked and increasingly hybrid public sphere, extending and transforming it to allow for and facilitate access to all kinds of content and participants (Benkler 2006; Chadwick 2013; Jenkins 2008). By their sheer ubiquity, these media contribute towards changing media ecologies and open new ways and forms of communications between citizens and their representatives. Social media, in spite of their short history, have increasingly been integrated in political communication and can be regarded as extensions and yet another twist of change in local and national public spheres. It is almost commonplace to point to the blurring of borders between public, private and political spheres, e.g. when local and national political elites invite citizens to join them in private moments on Facebook or discuss mundane issues or politics on Twitter (Enli and Thumin 2012). Social media not only add to the spaces where citizens can gain information, they are also sites that allow for political marketing, mobilisation, discussion, opinion formation and sources of news production and agenda setting.

This study seeks to map and understand intermedial agenda setting between social media and the traditional news media by using data from both local journalism and the social media activity of local politicians during the 2011 Norwegian local election campaigns. We study the tweets, Facebook updates 
and media coverage of a selection of political candidates from seven Norwegian parties in three different periods of the local election campaigns. We discuss what our findings add to the understanding of the networked public sphere and intermedial agenda setting and ask, first, whether social media, delimitated to Facebook and Twitter, were established as sources for local and regional newspapers; whether the social media updates that reached the local media had specific characteristics (types of updates, types of candidates, types of themes) and whether and how the candidates used traditional media content in their social media updates? As such, we approach social media within specific temporal and spatial frames in line with the boundaries of the polities and the reach of the news media included in our study. Second, we ask whether these spatial and temporal political process characteristics reflect on the agenda-setting processes between social media and the mainstream media, and if so, how.

\section{Mediatisation of politics in hybrid media landscapes}

Several strands of research and theory have shed light on our research questions. First, during election campaigns, political parties and their candidates have a number of ways of seeking to mobilise voters by attracting attention to the parties' issues and top candidates (Aelst, Thorbjørnsrud, and Aalberg 2012; Karlsen 2011a). Many of these involve processes of mediatisation, that is, that parties and politicians adapt their practices and messages to formats, deadlines, and genres that are journalistically attractive. Hjarvard $(2013,17)$ uses mediatisation "to understand the process whereby culture and society become increasingly dependent on media and their logic". He refers to the duality of the process in which the media have become social institutions in their own right as well as the sites for social interaction between institutions in society. According to this perspective, mediatisation is a "middlerange theory" of social change, valid for describing profound changes in modern, highly industrialised societies from the late twentieth century onwards. It takes as a starting point that contemporary Western societies are mediated democracies and places media power and agenda setting in a broader cultural perspective.

In terms of political communication, mediatisation refers to the fact that political actors, such as parties and candidates, are dependent on the media not only for gaining the attention of voters and for gaining access to communicative spaces but also as social institutions that frame and interpret political events, such as elections and party conventions. The media, for the most part, need parties and politicians as sources and political content providers. Both institutions influence each other's practices to the degree that the mediated politics can be regarded as characteristic of modern democracies (McNair 2000; Davis 2010; Skogerbø 1999).

Hjarvard, unlike Altheide (2013), for example, distinguishes between "mediatisation” and "mediation". The latter "describes the concrete act of communication by means of a type of media in a specific social context” $(2013,19)$. Accordingly, this is a study of mediation as we look at the manner in which political messages travel, interplay with or are simultaneously displayed on several media platforms, that is, from social to news media or vice versa. Unfortunately, Hjarvard's distinction between mediation and mediatisation may disguise rather than expose the processes that we examine.

"Mediatisation" is designed to grasp the complexity in the changes of various social institutions, such as politics and the media whereas "mediation" seems to refer to a unilinear distribution process. As such, mediation does not grasp the multidimensional, intermedial and crossmedial nature of election campaigns (Aelst, Thorbjørnsrud, and Aalberg 2012; Karlsen 2011a). Consequently, this is reflective of the interchangeable manner in which politicians use traditional news media, online media and social media for campaign purposes.

We argue that it is exactly this changing communication process, the fact that content travels across contexts, that is most interesting in seeking to understand how political communication changes. Chadwick (2011) conceptualises and describes how the political news circle operated in a hybrid media system in "the Bullygate" affair in Britain in 2010. His fascinating study shows how mainstream political journalists interact with elite and non-elite sources on Twitter and blogs in the constant production of news. In a hybrid system, online social and mainstream media are all part of the news circle, and news are often "broken" on social media either by journalists or by other actors in the circle. Politicians operate in hybrid media landscapes, and content travels across platforms, sometimes intentionally, sometimes because the networked nature of the public sphere and the social media simply 
allow it.

In practice, mediatisation and hybridity enrich the manner in which both parties and politicians as sources and journalists and editors can work in the daily struggle to set the agenda, both for their news services and, in part, for election campaigns. Elmelund-Præstekær et al. (2011) and Thesen (2013) argue that the insights of agenda-setting theory and mediatisation should be combined in order to understand the interplay between politics and the media. From our perspective, election campaigns contain many different communication practices, however, the main objective for parties and candidates is to be visible to voters so that they can attract support and, eventually, votes on Election Day. In order to attain visibility, candidates and parties use both well-known techniques for attracting journalistic attention and influence the media agenda as well as more novel channels for attracting attention from journalists and voters, such as blogging, Twitter and Facebook updates. There is no shortage of studies showing that social media have become tools and newsbeats for political journalists. Notwithstanding, this study seeks to trace the impact of social media activity on local political journalism.

\section{Election campaigns and local media logic}

In any election campaign, there will be a division of labour between the top political leaders, such as the national party leadership and the most centrally placed top candidates, and candidates who are less well known and running for regional or local seats. Whereas the first group can be described as celebrity politicians who operate in the national arena, politically and medially (Van Zoonen 2005; Craig 2014), the second run their campaigns in local and regional communicative environments. In election periods, celebrity politicians have much easier access to nationwide media than regional and local candidates. Most local candidates are not celebrities, are rarely exposed on national television, do not hold high positions in the party and, accordingly, draw less attention to their candidacies. They have the local media as their main arenas (Johansson 1998; Ekström, Johansson, and Larsson 2010; Johansson 2010; Skogerbø 2011). The local media nevertheless operate in a variety of public spaces that can be described in the same vein as national public spheres; they are fragmented, hybrid and hierarchical. In Scandinavia, local and regional newspapers have been the main stage for local politics and have been essential for local candidates and parties. In Norway, local and regional newspapers have retained a central position for politicians to reach their voters and as important sources of information for voters (Skogerbø and Winsvold 2011; Karlsen 2011b).

The coverage of election campaigns is generally also extensive in the local media, yet editors and political journalists are well aware that parties and candidates seek to set their own agendas and "win" the campaigns. Local and regional media have alternative editorial priorities and ways of working that impact on the manner in which they follow and report politics. One difference between nationwide and local media is the need to localise the news (Franklin 2006). For political candidates, this means that they also have to localise their messages on social media.

Several studies have pointed to the emergence of social media as news beats for the mainstream media. Broersma and Graham (2012) has found that Twitter has become an established source of news among major news media in the UK and the Netherlands. Their studies encompassed the largest newspapers, spanned several years and election campaigns in the two countries and proved that Twitter has become a news beat for political journalism. In the USA, Wallsten (2013) has used the same methods in a study of the coverage of the 2012 presidential election campaign in five large newspapers. His findings supported that Twitter also works as a news beat for the mainstream media in the USA. Hermida $(2010,2013)$ has reported on a number of studies on the importance of Twitter as both a source of and a distribution channel for news and points to the development within the service-privileging, event-based and event-driven communication. Local media have not been studied to the same extent as the large and nationwide media when it comes to how social media impact on local journalism. The present study seeks to address this gap by tracking whether and how the politicians' social media activity was picked up in local journalism.

\section{Social media as means of political communication}

There is no shortage of media stages on which to perform, but they do not share a similar value for politicians and voters. Within the local media landscape, social media constitutes one among many forms of communication. It is placed lower in the media hierarchies than the local news media but is 
possibly one of many sources that local journalism relies on. When observed as means of political communication, social media should be studied within the context of spatial and temporal boundaries. Politicians live and work in urban and rural spaces with varying characteristics, and citizens' ballots are valid only within the polity in which they have constitutional rights to participate.

Even in Scandinavia, where politics is party-centred rather than candidate-centred, political candidates need to attract attention to themselves, and being active on social media is one way of accomplishing this (Larsson and Kalsnes 2014). Social media offer parties and politicians options for personalising and designing their own messages and "dodging the gatekeepers" (Skovsgaard and Van Dalen 2013; Enli and Skogerbø 2013). Mastering the skills of being visible on all accessible communicative platforms, mediated as well as personal, is a necessary talent in local as well as international politics.

Among the variety of social media, Twitter has attracted the most scholarly interest. Twitter updates are publicly available, and software for collecting and analysing data from, for example, hashtags (\#) have been developed at a rapid pace (Bruns and Burgess 2012; Larsson and Moe 2012; Kalsnes, Krumsvik, and Storsul 2014). A number of recent studies show how Twitter messages travel within networks of persons that can be considered as opinion leaders (Bruns and Highfield 2013; Moe and Larsson 2013; Papacharissi and de Fatima Oliveira 2012). Several studies have found that Twitter users comment on the performance of media and politicians rather than engaging in direct political discussion (Larsson and Moe 2012; Burgess and Bruns 2012). We do not have a similar abundance of studies when it comes to the impact of other social media on journalism. Since Facebook requires bilateral acceptance, is often closed and does not allow other software or entities to track and easily collect data, we know less about the relationships between traditional media, journalists and sources on Facebook, YouTube, Instagram and many other closed or semi-closed media.

However, there is much evidence that social media have different functionalities and adaptabilities for different purposes. Politicians use social media for a diversity of reasons, for example, self-representation, keeping in contact with friends and family, political statements and discussions and conversation with voters. Facebook was by far the most popular social medium for politicians, as it was among voters in the 2011 election campaign in Norway (Enli and Skogerbø 2013). Holton et al. ( 2014) have found that Twitter users post links to spark conversations with followers or to find links to similar information, thereby simultaneously sharing and seeking information. Newspapers facilitate user involvement strategies in social media for newsgathering, deliberation and distribution, with a strong emphasis on the latter (Krumsvik 2013a). Ju, Jeong, and Chyi (2014) have found that Twitter is more effective than Facebook in terms of audience reach for the distribution of newspaper content; however, social media subscribers continue to represent a small fraction of print and Web users despite the hype about the distribution potential of social media. Still, it is striking that Facebook is a much more used site than Twitter, not only among the population but also among politicians (Johnson and Perlmutter 2010; Skovsgaard and Van Dalen 2013; Westling 2007; Williams and Gulati 2013; Enjolras et al. 2013).

\section{Norwegian party and media landscapes}

The background of the study is the Norwegian political system and media structure. Norway is a stable democracy with a parliamentary government, a multiparty system and well-organised membership parties. Over time, the traditional cleavage structures have weakened, as has the support for the smaller parties. Still, the left-right conflict has remained significant. Consequently, the party system can be described in terms of how parties are placed on the left-right continuum (Fig. 1).

\section{$<$ FIGURE 1> ABOUT HERE}

The Norwegian electoral system consists of direct elections and proportional representation. It is, as is common in Europe, party-centred as opposed to the party system of the USA, which is typically candidate-centred. The central party organisations draw up main campaign strategies to guide local and regional campaigns, but particularly in local campaigns, there is much space for the local adaptation of general messages and strategies, the degree of freedom varying somewhat between the parties. A total of 429 municipalities make up the political and administrative level of local government as well as the constituencies for local elections. Elections are held every two years at fixed dates, interchangeably 
between parliamentary and local elections. Norwegian election studies divide the Norwegian campaign into two phases, "the long campaign", comprising approximately the year preceding Election Day, and the "short campaign", the intensive final four weeks (Aardal, Krogstad, and Narud 2004).

Hallin and Mancini $(2004,11)$ regard the Norwegian media system as a typical example of the Democratic Corporatist Model. It can be characterised by the historical coexistence of commercial media and political parallelism, meaning that many media, typically newspapers, have been party press or tied to civic organisations. The state is active in designing public media policy, including public service broadcasting and press subsidies; at the same time, there are strong legal and institutional barriers against interference in editorial freedom. In Norway, as elsewhere, the prominence of commercial media has increased in recent years, thereby weakening the characteristics of the Democratic Corporatist Model (Herkman 2009; Krumsvik 2013b).

Equally important for understanding the role of the media in election campaigns are two other traits of the Norwegian media structure: first, the ubiquity of media channels all over the country. The public broadcaster, NRK, provides regional as well as national television and radio services. The most important commercial TV channel, TV2, provides nationwide broadcasts on several channels, including news and specific election coverage. Approximately 225 newspapers, most of which are local, and many only issued a few days a week, cover the entire country, combining printed and online issues (Høst 2013). Newspaper readership is high although the print component is in decline.

In addition, the use and accessibility of online and mobile media are very high. All traditional media operate extensive online and mobile media services. In 2012, 97 percent of Norwegians had Internet access, 90 percent by broadband, and the number of mobile subscriptions, 5.8 million, exceeded the total population. ${ }^{1}$ In 2013, 79 percent of the population owned a smartphone. Social media were widely used although the share of users varied largely between different services, such as Facebook, Twitter and YouTube. Sixty-seven percent of the Norwegian population used Facebook and eight percent used Twitter on a daily basis. ${ }^{2}$ Both Twitter and Facebook are integrated with news media as sources and spaces for debates.

\section{Data and methods}

The data material consisted of newspaper items (print and online) and social media updates from the last four weeks of the 2011 local election campaigns. During the campaign, we followed a sample of 21 top local candidates from seven parties in five municipalities, Oslo, the capital of Norway, Drammen, Stavanger, Tromsø and Kongsvinger. The choice of these five municipalities rested on several reasons that aimed to produce data that would give a valid and robust picture of how social media were included in the reporting of politics in local settings. In three of the municipalities, two or more newspapers were issued; all five municipalities were also covered by other media (radio, regional broadcasts and online news). The newspapers (both print and online versions) included in the analysis were Aftenposten (Oslo), Dagsavisen (Oslo), Drammens Tidende (Drammen), Stavanger Aftenblad (Stavanger), Rogalands Avis (Stavanger), Glåmdalen (Kongsvinger), Nordlys (Tromsø) and Tromsø/iTromsø (Tromsø). The municipalities are located in different areas of the country and are of different sizes in terms of geography and population. By Norwegian measures, Oslo and Stavanger are cities, Drammen and Tromsø are medium-sized towns, and Kongsvinger is a small town. Another reason for the selection was that Oslo was a campaigning ground not only for local but also for top national politicians and might therefore show a different pattern than other constituencies. Finally, there were internal economic research considerations for selecting these municipalities. We had conducted previous studies on Stavanger, Drammen, Tromsø and Kongsvinger, which meant that selecting these municipalities opened opportunities for comparisons as well as possibilities for gaining insights over time about local journalism and the intermediality between traditional and social media. We followed the local candidates in local newspapers, on Facebook and Twitter for two weeks of the long campaign period, in the entire short campaign before Election Day on 12 September 2011 and in a two-week period after the election. We collected the social media data manually. Updates were copied from the candidates' Twitter accounts and their public Facebook profiles. Searches in the Norwegian database for online and print newspapers provided newspaper items published in online and/or print newspapers on each of the 21 candidates. Altogether, 2,615 items were sampled, 43 percent were newspaper articles, and 60 percent were social media postings ( $70 \%$ Facebook, $30 \%$ Twitter). The coding of the material was done by 
several coders using online coding tools (Questback, SPSS). The data were analysed by quantitative content analysis and by means of standard statistical tools for analysis. By using these methods, we obtained reliable and valid data although not statistically representative of all types of Norwegian municipalities or journalistic practices. The study should however generate theoretically generalisable insights, both in the Norwegian setting and in countries with similar media ecologies and party-centred political systems.

\section{Findings}

Our research questions focused on the position of social media in local election campaigns and local public spaces; whether social media had established themselves as sources for the local news media; whether the social media content reaching the local media had specific characteristics and the degree to which local candidates used social media as campaigning tools. In our reporting, we will commence with some findings that are distinctly different from those reported by Broersma and Graham (2012) and Wallsten (2013).

\section{Social media were not established as sources for local newspapers}

In our sample of the coverage of candidates and parties in local and regional printed and online newspapers, we found little evidence that social media were established sources for local journalists. Only a few pieces of news referred to social media as sources in spite of the fact that some of the newspapers were among the largest in Norway, several of the candidates were nationally well known, and many were actively promoting their candidacies on Facebook and Twitter. We expected to find references to social media postings by or concerning these candidates in the newspapers; but this was not the case. If indeed social media were sources for the coverage of the candidates, they were not cited as such by the media.

As Table 1 shows, the limited number of references to social media was not the result of lack of activity among the candidates. Altogether, the candidates posted 1,042 updates on Facebook and 441 on Twitter during the one-month period analysed. To varying degrees, the candidates linked to legacy media, national and local.

\section{$<$ TABLE 1>}

Table 1 shows that about one-fifth (21\%) of the social media updates contained links to local or national media; thus, as could be expected, the candidates used updates to redistribute more media content from local than from national media. In other words, we find cross- and intermediality in the candidates' own campaigning efforts although we could not trace the influence from social media to the newspapers. This does not mean that journalists did not follow candidates on social media. Quite the opposite; both unpublished analyses of our own data and a number of studies carried out in Scandinavia and elsewhere show, as referenced above, that social media and, in particular, Twitter have become established sources for journalists.

The candidates rarely retweeted and reposted links to news coverage about themselves. Their linking was to news stories about the party, the campaign and other issues reported in the local and national news media. What we see in our material is that social media use, including linking, is one of several campaign practices. Since references to social media updates were so few, we could not draw any inferences about the character of updates reaching the mainstream media. The examples we have are simply too few to derive patterns.

\section{Differences between the parties: initiatives and agenda setting}

In terms of visibility and media presence, the efforts of the candidates in driving issues and branding their candidacies on social media had several objectives; they were partly directed at voters and 
partly at attracting attention and setting the agenda for the news media. Although we found little evidence of intermedial agenda setting by reference to social media updates, it was clear that the parties and their candidates attempted and succeeded at getting published and being visible in the newspapers. These findings emerged from references in the news stories to press conferences, comments, press releases and other sources stemming from the parties or the candidates and in the many letters to the editors, comments and other items that either referenced or originated from candidates and parties.

When we look at all kinds of parties' as well as politicians' initiatives to set the agenda published by the newspapers, we find that the small parties, the Liberals, the Centre Party (Sp), the Christian Democratic Party (Krf) and the Socialist Left Party (SV) were, in absolute terms, more visible in the local newspapers than the large parties. These initiatives included different items, such as news stories, comments, letters to the editor and quotations from social media. However, by restricting our analysis only to news stories in which we could identify agenda setting, we find that the candidates from the three largest parties attracted more journalistic attention (Table 2).

\section{$<$ TABLE 2>}

Table 2 shows the distribution between the parties and their candidates concerning their ability to set the agenda in news stories and other types of newspaper stories. We expected the large parties to be most successful, and overall, the largest parties (Ap, H, Frp) set the agenda in 56 percent of the news stories. Nevertheless, the candidates of the small Liberal Party were in focus in 19 percent of the news stories, more often than the candidates of the Labour and Progressive parties. Only the Conservatives were more successful. At the other end, the Christian Democratic Party attracted least attention to their candidates. The reasons why the large parties were focused in news stories may seem obvious. They were the main contestants in all five constituencies; fighting for the majority and mayoral positions explains their journalistic attractiveness. Both their local candidates and the party leadership were well known to both the media and the voters, thereby fulfilling many of the journalistic criteria for hitting the headlines. The large parties generated news stories in the local or regional newspapers e.g. when the local party branch hosted visits by party leaders or other celebrity politicians with high "media capital" (Skogerbø and Karlsen 2014; Davis 2010; Van Zoonen 2005). One illustrative example was a visit by Prime Minister Jens Stoltenberg (Ap) to Stavanger where he also took part in a televised debate set in an institution for the elderly. The debate also included the top local and regional representatives from the main opposition parties in the constituency. Both the Labour party's top candidate and the top candidate of the main contestant, the Conservative Party $(\mathrm{H})$, were in focus in a number of news stories directly connected to the Prime Minister's visit. There were similar examples of news stories concerning visits by celebrity politicians from the Progress Party (Stavanger) and the Labour Party (Drammen and Tromsø).

It is more difficult to explain why candidates of the small parties were almost equally successful in attracting media focus. It may be related to the positions that the candidates of the small parties held in the election campaigns; several of them ran for unsecure mandates; they could not rely on the sheer size of the party for their election or re-election. Their position thus demanded activity in local and regional news media as well as in social media in order to mobilise a sufficient number of voters to secure party representation in local or regional decision-making bodies. These candidates had to be visible in traditional media as well as on alternative platforms, seeking to draw voters' and journalists' attention in their direction (Skogerbø and Karlsen 2014). A story about a candidate from a small party fighting to win a seat was likely to be newsworthy. For the large parties, this might explain why they did not dominate the election news. In one of our selected municipalities, for instance, the Labour Party was rarely present on any media platform, traditional or social, during the campaign, but the party nevertheless returned several candidates to the municipal council. In this particular local setting, the position of the party in the constituency was so strong that the need to obtain visibility and media coverage was probably less important for the candidates and, therefore, almost non-existent.

As Table 3 displays, we also see party differences concerning the ways in which the candidates were presented in the local news and the manner in which they staged themselves on social media. 
There is no surprise in the totals; the candidates were generally more profiled on social media than in the newspapers. Table 3 further substantiates the findings that with the exception of the Christian Democrats (Krf), the small parties (V, SV and Sp) obtained less media coverage in relation to their postings on social media than the large ones. The party had approximately the same amount of social media postings as press items although rather few of both types.

\section{$<$ FIGURE 2> ABOUT HERE}

When we combine the variables - parties, linking practices and initiative - we observe some interesting patterns. Figure 2 shows that the politicians from the seven parties varied substantially in their social media activities. Three parties, the Labour, Conservative and Liberal parties were highly active both in terms of linking to legacy media and in taking initiatives for media coverage whereas the Christian Democrats and the Centre Party found themselves in the less active square of the table, with the Socialist Left Party and the right wing Progress Party in the intermediate position.

We also observe spatial differences. The five municipalities represented five different polities with varying sizes and levels of intensity in terms of political conflict. Although the left-right conflict was the dominant political cleavage in all these municipalities, there were substantial differences in the intensity and the coverage of the campaign.

\section{$<$ FIGURE 3> ABOUT HERE}

Figure 3 extends the analysis even further. We see that whereas in one municipality (Stavanger), the candidates were generally active both in linking and agenda-setting initiatives, in another (Kongsvinger), activity was generally low on both fronts.

\section{Discussion and conclusion}

In order to address the implications of our findings, we return to our research questions. Our analysis showed few indications that social media set the agenda and influenced local journalism. These findings, or more correctly, non-findings of social media as sources, may have several explanations, some referring to our methods, others substantial. With reference to the method employed, the fact that we did not track every news story in the period, only those that specifically concerned our selected candidates, may be one explanation. The lack of references to social media apparently leads to the conclusion that social media had little or no impact on political journalism in the newspapers we studied. However, the fact that social media were not cited does not mean they were not sourced. There may have been other articles concerning the election or other issues where social media were indeed sourced but were not included in our material. Moreover, and more substantially, social media may have been sourced but not mentioned in news articles, as there is no reason to believe that Norwegian journalists do not follow politicians on Twitter.

However, sourcing social media is likely to be considered a less credible journalistic method than quoting candidates directly in interviews. In Norway, and particularly in the local and regional constituencies, there is little distance between the local newsrooms and local politics, and it is easy to gain access to parties and politicians. Both parties, journalists and candidates, have stakes in getting a good story out. For the candidates, local newspapers rank higher in the media hierarchy than social media as they are so widely read (Skogerbø 2011). For journalists, the interview is likely to be a more prestigious tool of journalism than quoting social media (Ekström and Patrona 2011). This explanation allows for the likely scenario that although most political journalists are familiar with social media, both through their institutions and through individual use, quoting social media does not count as equally valuable as an interview. Examples from our newspaper stories seem to support this as the few quotes that surface in our material either substitute for interviews or are direct quotes from Twitter that illustrate or "fill in" a story.

We found less evidence of intermedial agenda setting than anticipated. The parties and candidates succeeded nevertheless in being visible and setting the agenda in the newspapers. Particularly interesting was the fact that both large and small parties were successful at setting the agenda. We suggest that the newsworthiness of the small parties may be explained with reference to the positions of 
the parties and the candidates in the constituencies. Small parties and candidates campaigning for insecure seats may have been more active in their agenda-setting efforts than were candidates from large parties that could count on being represented. Further, small parties are often coalition partners in local government and hold key political positions that determine the colour and power of the winning side. It is also likely that the local candidates and parties differed in the degree to which their campaign practices were mediatised. Returning to Table 2, it is hardly surprising that the traditional Christian Democrats rarely initiated news stories.

So what does the lack of intermediality and the seemingly limited importance of social media mean? First, the results perhaps simply express that local newspapers and journalists had little or no interest in social media and, therefore, did not regard them as interesting sources of election news. Newspapers remained the main arenas in which the local elections were played out; in other words, traditional journalism mattered more than social media. A second explanation that is also linked to our research question - whether and how the candidates used media stories in their social media updatesplaces more emphasis on the strategies of the candidates. The candidates may have used dual strategies for setting the agenda in social media and news media; they may have chosen to talk to voters by seeking to set the agenda for news coverage in local newspapers, for instance, by originating stories and trying to control the mediation process. This would explain why we found so many different media initiatives by particularly the small parties. Politicians use social media for many reasons, one of which is to talk to and discuss with voters without involving the news media as intermediaries. In other words, candidates may seek to set the agenda in social media, completely bypassing the agenda of legacy media, or may create links to news stories for rhetorical support. This explanation accounts for the fact that the tweets and Facebook updates that we studied contained few links to local media coverage and local issues, rather they reflected the multifaceted and cross-medial character of campaign communication strategies that have evolved in parallel with increasingly fragmented and hybrid media ecologies.

A third explanation draws attention to the spatiality of the campaigns, namely, the fact that campaigns not only take place within the boundaries of constituencies but also within those of local media ecologies. The party differences presented in Figure 3 illustrate our discussion on mediatisation, suggesting that the characteristics of the constituencies and media ecologies have a bearing on how the campaigns are carried out. Although the pattern indicates that parties are successful to varying degrees when it comes to obtaining media coverage, it may also signify that parties have different election strategies varying with their history, structure, resource base and the composition of their core electorate. Labour and the Conservatives are large and dominant parties in Norwegian politics; therefore, they are equipped with more resources and well-oiled election campaign machineries that used all types of campaigning tools. The minor parties, Krf and Sp, do not have equally strong organisations. Both have small core voter groups (farmers/rural voters and active Christian/religious voters, respectively), fewer resources and fewer options for attracting attention as their positions are less decisive in the local power play. Figure 4 shows the differences between the constituencies regarding the intensity of the political competition and the potential impact of such factors on coverage in legacy media as well as the efforts that the candidates put into attracting attention to themselves. Two municipalities, Stavanger and Kongsvinger, represent opposite poles. In the first, a city, there was a close race between the Labour and Conservative candidates for the position of mayor. In the second, a town, the election campaign was carried out with less intensity in spite of the fact that the same parties competed for similar positions. The other three municipalities place themselves in intermediary positions in terms of the activity of the candidates in linking to and initiating stories in the news media. It seems reasonable to suggest that in a setting where resources had to be redistributed, agenda-setting initiatives in social media received less priority than, for example, personal communication with voters and direct contact with local journalists. Our study clearly showed that social media were adopted and included in the toolbox of local candidates running in the 2011 local election in Norway; however, in contrast to international findings, we could not establish that these media had entered the local news circle. In spite of the fact that wellknown and profiled candidates were active on social media, these updates were not evident in journalistic stories and agenda setting. We have suggested a number of explanations above that mainly draw on the characteristics of the local media ecology and the Norwegian political setting. These explanations suggest that social media may matter less in the context of local journalism and local election campaigns than in international or nationwide contexts. We cannot know whether our findings are bound in time and space to the coverage of 2011 Norwegian election campaign, however, we 
hypothesize that there are differences in the journalistic practices of covering local and general election campaigns. Local politicians and party organisations are likely to be and remain easier to source than national and international top politicians and party leaderships; therefore, local journalistic practices concerning social media sourcing and may remain different from what we find when studying the large media with a nationwide or international reach. Our findings accordingly also suggest that for local politicians social media are less important as tools for setting the agenda in the local media; they may be more important as communication channels directly with the voters.

\section{NOTES}

1. Statistisk årbok 2013, http://www.ssb.no/befolkning/artikler-ogpublikasjoner/_attachment/140702? ts=1415a7ca078, tables 440, 44 (Statistical Yearbook 2013). Accessed 23.1.2014.

2. http://www.tns-gallup.no/arch/_img/9110040.pdf. Accessed 23.01.2014. 


\section{REFERENCES}

Aardal, Bernt, Anne Krogstad, and Hanne Marthe Narud. 2004. I valgkampens hete: strategisk kommunikasjon og politisk usikkerhet. Oslo: Universitetsforl.

Aelst, Peter van, Kjersti Thorbjørnsrud, and Toril Aalberg. 2012. "The Political Information Environment During Election Campaigns." In How Media Inform Democracy: A Comparative Approach, edited by Toril Aalberg and James Curran, S. 50-63. London: Routledge.

Altheide, David L. 2013. "Media Logic, Social Control, and Fear." Communication Theory 23 (3): 223-238. doi: 10.1111/comt.12017.

Benkler, Yochai. 2006. The Wealth of Networks: How Social Production Transforms Markets and Freedom. New Haven, Conn.: Yale University Press.

Broersma, Marcel, and Todd Graham. 2012. "Social Media as Beat." Journalism Practice 6 (3): 403-419. doi: 10.1080/17512786.2012.663626.

Bruns, Axel, and Jean Burgess. 2012. "Researching News Discussion on Twitter." Journalism Studies 13 (5-6): 801-814. doi: 10.1080/1461670X.2012.664428.

Bruns, Axel, and Tim Highfield. 2013. "Political Networks on Twitter." Information, Communication \& Society 1-25. doi: 10.1080/1369118X.2013.782328.

Burgess, Jean, and Axel Bruns. 2012. "(Not) the Twitter Election." Journalism Practice 6 (3): 384-402. doi: 10.1080/17512786.2012.663610.

Chadwick, Andrew. 2011. "The Political Information Cycle in a Hybrid News System: The British Prime Minister and the "Bullygate" Affair." The International Journal of Press/Politics 16 (1): 3-29. doi: 10.1177/1940161210384730.

Chadwick, Andrew. 2013. The Hybrid Media System: Politics and Power. Oxford: Oxford University Press.

Craig, Geoffrey. 2014. "Kevin’s Predicaments: Power and Celebrity Across the Political and Media Fields." The International Journal of Press/Politics 19 (1): 24-41. doi: 10.1177/1940161213508813.

Davis, Aeron. 2010. Political Communication and Social Theory. Hoboken: Taylor \& Francis.

Ekström, Mats, Bengt Johansson, and Larsåke Larsson. 2010. "Journalism and Local Politics." In The Routledge Companion to News and Journalism, edited by Stuart Allen. Milton Park: Routledge.

Ekström, Mats, and Marianna Patrona. 2011. Talking Politics in Broadcast Media: Cross-Cultural Perspectives on Political Interviewing, Journalism and Accountability. Amsterdam: John Benjamins.

Elmelund-Præstekær, Christian, David Nicolas Hopmann, and Asbjørn Sonne Nørgaard. 2011. "Does Mediatization Change MP-Media Interaction and MP Attitudes toward the Media? Evidence from a Longitudinal Study of Danish MPs." The International Journal of Press/Politics 16 (3): 382-403. doi: 10.1177/1940161211400735.

Enjolras, Bernard, Rune Karlsen, Kari Steen-Johnsen, and Dag Wollebæk. 2013. Liker - liker ikke: sosiale medier, samfunnsengasjement og offentlighet. Oslo: Cappelen Damm akademisk.

Enli, Gunn Sara, and Eli Skogerbø. 2013. "Personalized Campaigns in Party-Centred Politics." Information, Communication \& Society 16 (5): 1-18. doi: 10.1080/1369118X.2013.782330.

Enli, Gunn Sara, and Nancy Thumin. 2012. "Socializing and Self-Representation Online: Exploring Facebook." Observatorio (OBS*) Journal 6 (1): 87-105.

Franklin, Bob. 2006. Local Journalism and Local Media: Making the Local News. London; New York: Routledge, Kindle edition.

Hallin, Daniel C., and Paolo Mancini. 2004. Comparing Media Systems: Three Models of Media and Politics. Cambridge: Cambridge University Press.

Herkman, Juha. 2009. "The Structural Transformation of The Democratic Corporatist Model: The 
Case of Finland." Javnost-the Public 16 (4).

Hermida, Alfred. 2010. "Twittering the News." Journalism Practice 4 (3): 297-308. doi: 10.1080/17512781003640703.

Hermida, Alfred. 2013. "\#Journalism." Digital Journalism 1 (3): 295-313. doi: 10.1080/21670811.2013.808456.

Hjarvard, Stig. 2013. The Mediatization of Culture and Society. Milton Park: Routledge.

Holton, Avery E., Kang Baek, Mark Coddington, and Carolyn Yaschur. 2014. "Seeking and Sharing: Motivations for Linking on Twitter." Communication Research Reports 31 (1): 33-40.

Høst, Sigurd. 2013. Avisåret 2012. Vol. 37. Volda: Møreforsking.

Jenkins, Henry. 2008. Convergence Culture: Where Old and New Media Collide. New York: New York University Press.

Johansson, Bengt. 1998. Nyheter mitt ibland oss. Kommunala nyheter, personlig erfarenhet och lokal opinionsbildning, Göteborgsstudier i journalistik och masskommunikation 15. Göteborg: Institutionen för journalistik och masskommunikation.

Johansson, Bengt. 2010. "I skuggan av riksdagsvalet - lokala medievalrörelser och andra rangens val." In Kommunvalet 2006. Väljare och partier i den lokala demokratin, edited by Folke Johansson. Göteborg: Centrum för forskning om offentlig sektor, CEFOS, och Statsvetenskapliga institutionen, Göteborgs universitet

Johnson, Thomas J., and David D. Perlmutter. 2010. "Introduction: The Facebook Election." Mass Communication and Society 13 (5): 554-559. doi: 10.1080/15205436.2010.517490.

Ju, Alice, Sun Ho Jeong, and Hsiang Iris Chyi. 2014. "Examining the Effectiveness of Facebook and Twitter as News Platforms." Journalism Practice 8 (1).

Kalsnes, Bente, Arne H. Krumsvik, and Tanja Storsul. 2014. "Social Media as Political Backchannel: Twitter Use During Televised Election Debates in Norway." Aslib Journal of Information Management 66 (3).

Karlsen, Rune. 2011a. "Still Broadcasting the Campaign: On the Internet and the Fragmentation of Political Communication with Evidence from Norwegian Electoral Politics." Journal of Information Technology \& Politics 8 (2): 146-162. doi: 10.1080/19331681.2011.536419.

Karlsen, Rune. 2011b. "Velgernes valgkamp." In Det politiske landskap. En studie av stortingsvalget 2009, edited by Bernt Aardal. Oslo: Cappelen Damm.

Krumsvik, Arne H. 2013a. "Towards a Typology of Strategies for User Involvement." In Handbook of Social Media Management, edited by M. Friedrichsen and W. MühlBenninghaus, 655-669. Berlin: Springer.

Krumsvik, Arne Håskjold 2013b. "Freedom of Expression and the Professionalization of Journalism." In Nordic Media Trends, edited by Ulla Carlsson. Göteborg: Nordicom.

Larsson, Anders Olof, and Bente Kalsnes. 2014. "Of course we are on Facebook" - Use and nonuse of social media among Swedish and Norwegian Politicians." European Journal of Communication.

Larsson, Anders Olof, and Hallvard Moe. 2012. "Studying political microblogging: Twitter users in the 2010 Swedish election campaign." New Media \& Society 14 (5): 729-747. doi: $10.1177 / 1461444811422894$.

McNair, Brian. 2000. Journalism and Democracy. An Evaluation of the Political Public Sphere. London and New York: Routledge.

Moe, Hallvard, and Anders Olof Larsson. 2013. "Untanglisg a Complex Media System." Information, Communication \& Society 1-20. doi: 10.1080/1369118X.2013.783607.

Papacharissi, Zizi, and Maria de Fatima Oliveira. 2012. "Affective News and Networked Publics: The Rhythms of News Storytelling on \#Egypt." Journal of Communication 62 (2): 266282. doi: 10.1111/j.1460-2466.2012.01630.x.

Skogerbø, Eli. 1999. "Normativ teori, medier og demokrati." In Medier - institusjoner og historie, 
39-53. Fagbokforlaget, Bergen.

Skogerbø, Eli. 2011. "'Everybody Reads the Newspaper': Local Newspapers in the Digital Age." In Local and Regional Media - Democracy and Civil Society Shaping Processes, edited by Ilona Biernacka-Ligięza and Lesław Koćwin, 357-373. Nowa Ruda-Wrocław: Wydawnictwo MARIA.

Skogerbø, Eli, and Rune Karlsen. 2014. "Mediatisation and Regional Campaigning in a Party Centred-System: How and Why Parliamentary Candidates Seek Visibility." Javnost-The Public 21 (2).

Skogerbø, Eli, and Marte Winsvold. 2011. "Audiences on the Move? Use and Assessment of Local Print and Online Newspapers." European Journal of Communication 26 (3): 214229. doi: 10.1177/0267323111413112.

Skovsgaard, Morten, and Arjen Van Dalen. 2013. "Dodging the Gatekeepers?" Information, Communication \& Society 17 (5): 1-20. doi: 10.1080/1369118X.2013.783876.

Thesen, Gunnar. 2013. "Political Agenda Setting as Mediatized Politics? Media-Politics Interactions from a Party and Issue Competition Perspective." The International Journal of Press/Politics. doi: 10.1177/1940161213515756.

Van Zoonen, Liesbet. 2005. Entertaining the Citizen: When Politics and Popular Culture Converge. Lanham, Md.: Rowman \& Littlefield.

Wallsten, Kevin. 2013. "'New Media' in the Newsroom: Twitter's Influence on Print Media Coverage During the 2012 Campaign " Newspaper Research Journal 35 (2).

Westling, Mike. 2007. "Expanding the Public Sphere: The Impact of Facebook on Political Communication." Society 28 (5): 835-860.

Williams, Christine B., and Girish J. 'Jeff' Gulati. 2013. "Social Networks in Political Campaigns: Facebook and the Congressional Elections of 2006 and 2008." New Media \& Society 15 (1): 52-71. doi: 10.1177/1461444812457332. 


\section{Authors contact details}

Eli Skogerbø, (corresponding author), Department of Media and Communication, University of Oslo, eli.skogerbo@media.uio.no

Arne H. Krumsvik, Department of Journalism and Media Studies, Oslo and Akershus University College of Applied Sciences, Arne.krumsvik@hioa.no 
Table 1. Political parties and social media posting of URLs to local and national media - 2011 percentages for each party. Percent. N=1483.

\begin{tabular}{|c|c|c|c|c|c|c|}
\hline Political party & Total postings & Facebook & Twitter & $\begin{array}{c}\text { URLs to } \\
\text { national } \\
\text { media }\end{array}$ & $\begin{array}{c}\text { URLs to } \\
\text { local } \\
\text { media }\end{array}$ & $\begin{array}{c}\text { Total } \\
\text { postings } \\
\text { with } \\
\text { URL’s to } \\
\text { media }\end{array}$ \\
\cline { 2 - 7 } & $\mathrm{N}$ & $\%$ & $\%$ & $\%$ & $\%$ & $\%$ \\
\hline V & 354 & 40 & 60 & 7 & 7 & 14 \\
\hline Ap & 336 & 78 & 23 & 8 & 9 & 17 \\
\hline H & 315 & 85 & 15 & 12 & 27 & 39 \\
\hline SV & 201 & 57 & 43 & 11 & 7 & 18 \\
\hline Frap & 143 & 85 & 15 & 9 & 14 & 23 \\
\hline SP & 84 & 100 & 0 & 8 & 13 & 21 \\
\hline Krf & 50 & 98 & 2 & 14 & 50 & 64 \\
\hline TOTAL & 1483 & 70 & 30 & 9 & 12 & 21 \\
\hline
\end{tabular}


Table 2. Newspaper stories in 2011 in which the main angle was on a candidate who managed to set the agenda. Absolute figures and percent. $N=201$

\begin{tabular}{|l|c|c|c|c|c|}
\hline \multicolumn{1}{|c|}{ Party } & \multicolumn{2}{|c|}{ News story } & \multicolumn{2}{c|}{ Other story } & \\
\hline & $\mathrm{N}$ & $\%$ & $\mathrm{~N}$ & $\%$ & $\mathrm{~N}$ \\
\hline Labour (AP) & 18 & 16 & 16 & 18 & 34 \\
\hline Conservative (H) & 26 & 24 & 10 & 11 & 36 \\
\hline Progress (FrP) & 18 & 16 & 8 & 9 & 26 \\
\hline Centre (Sp) & 11 & 10 & 8 & 9 & 19 \\
\hline Christian Democrat (KrF) & 4 & 4 & 12 & 13 & 16 \\
\hline Socialist Left (SV) & 12 & 11 & 15 & 16 & 27 \\
\hline Liberal (V) & 21 & 19 & 22 & 24 & 43 \\
\hline Total & 110 & 100 & 91 & 100 & 201 \\
\hline
\end{tabular}


Table 3. Postings by candidates and newspaper articles in 2011 where the candidates were the central figure. Absolute figures and percent. $N=1487$

\begin{tabular}{|l|l|l|l|l|l|l|}
\hline & \multicolumn{2}{l}{ Social Media } & Print/Online news & \multicolumn{2}{l|}{ Total } \\
\hline & $\mathrm{N}$ & $\%$ & $\mathrm{~N}$ & $\%$ & $\mathrm{~N}$ & $\%$ \\
\hline Labour (Ap) & 337 & 65 & 184 & 35 & 521 & 100 \\
\hline Conservative (H) & 316 & 62 & 197 & 38 & 513 & 100 \\
\hline Progress (Frp) & 143 & 56 & 111 & 44 & 254 & 100 \\
\hline Centre (SP) & 84 & 69 & 38 & 31 & 122 & 100 \\
\hline Christian Democrat (Krf) & 50 & 53 & 44 & 47 & 94 & 100 \\
\hline Socialist Left (SV) & 201 & 72 & 79 & 28 & 280 & 100 \\
\hline Liberal (V) & 356 & 81 & 86 & 20 & 442 & 101 \\
\hline Total & 1487 & 67 & 739 & 33 & 2226 & 100 \\
\hline
\end{tabular}

Notes: $X^{2}(6, N=2226)=68.803, p<.001$ 
Figure 1: The seven parties in the Norwegian Parliament 2005-2013, presented along the leftright axis. (Norwegian acronyms).

\begin{tabular}{|l|l|l|l|l|l|l|}
\hline $\begin{array}{l}\text { Socialist Left } \\
\text { Party (SV) }\end{array}$ & $\begin{array}{l}\text { Labour Party } \\
\text { (Ap) }\end{array}$ & $\begin{array}{l}\text { Centre Party } \\
\text { (Sp) }\end{array}$ & $\begin{array}{l}\text { Christian } \\
\text { Democratic } \\
\text { Party (Krf) }\end{array}$ & $\begin{array}{l}\text { Liberal Party } \\
\text { (V) }\end{array}$ & $\begin{array}{l}\text { Conservative } \\
\text { Party (H) }\end{array}$ & $\begin{array}{l}\text { Progress Party } \\
\text { (Frp) }\end{array}$ \\
\hline
\end{tabular}

Note: The Green Party was represented by one MP from 2013. 
Figure 2. Linking vs. initiative: Parties

Linking vs Initiative: Parties

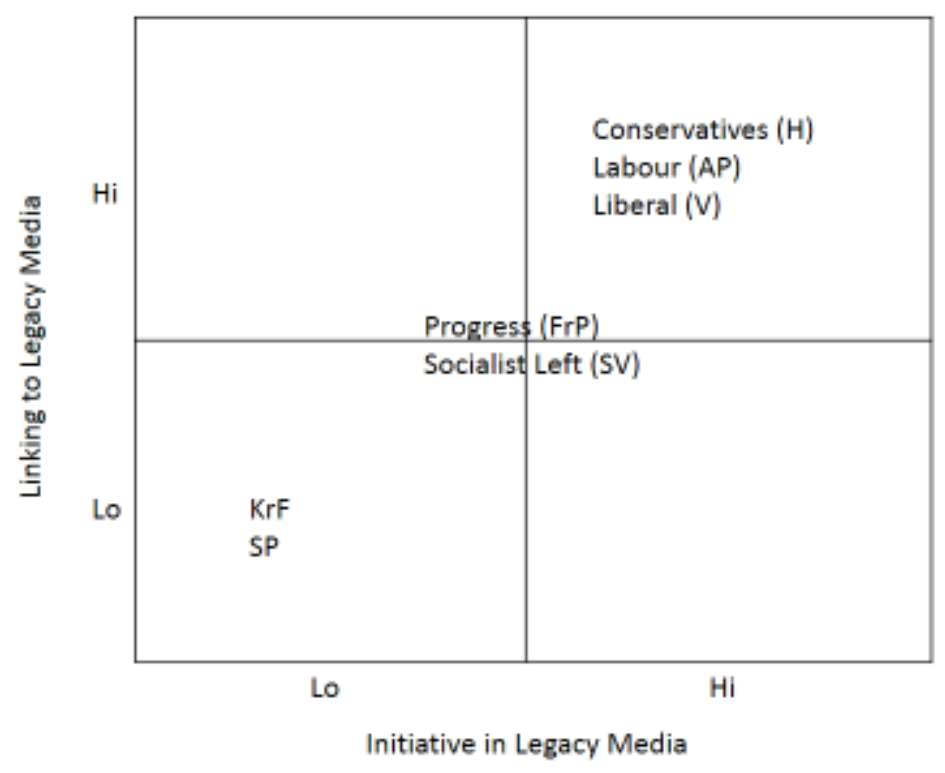


Figure 3: Linking practices and initiatives by municipalities - 2011.

\section{Linking vs Initiative: Cities}

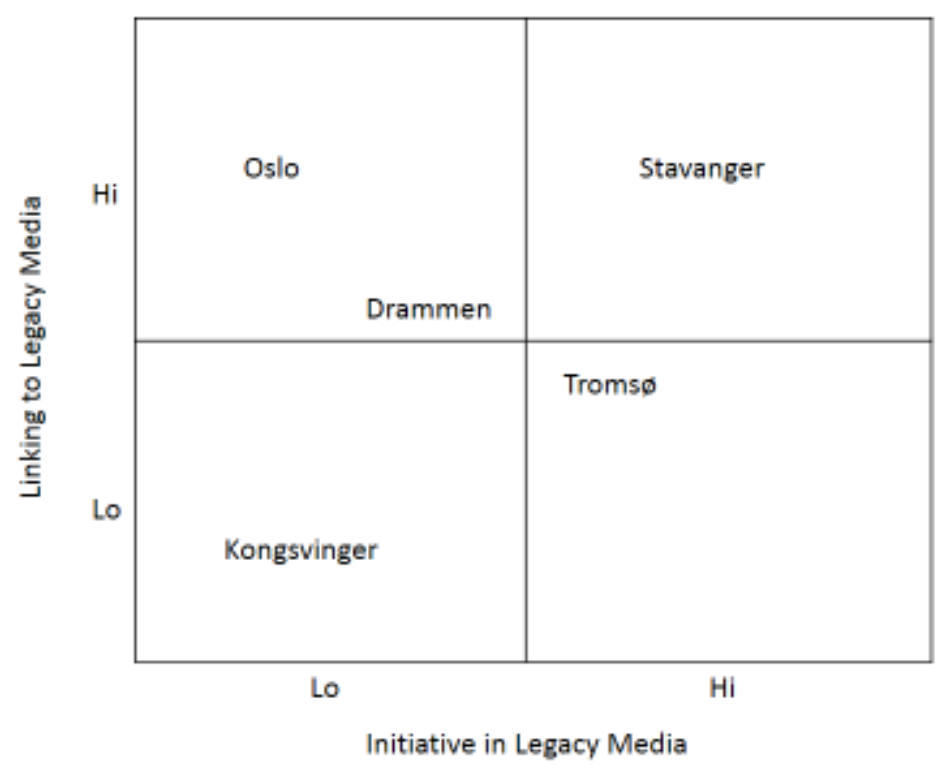

